\title{
On Fiduciary Duties of Controlling Shareholders of Targeted Corporation
}

\author{
Jinlong Zhao \\ College of Political Science and Law, Hebei University, China \\ E-mail: lw4zjl@126.com \\ Si Lv \\ College of Political Science and Law, Hebei University, China \\ E-mail: lvsi0075@hotmail.com
}

Received: July 11, 2011

Accepted: August 15, 2011

doi:10.5539/jpl.v4n2p85

This paper is one scientific research achievements of 2011 Hebei Province Social Science Funding Project "Shareholder Democracy Theory and the Construction of Shareholder Democracy Mechanism"(No.HB11FX008).

\begin{abstract}
In the acquisition of listed corporation, the controlling shareholders who either hold a certain number of shares, or play a decisive role in the transfer of corporation control. Compared with the minority shareholders, controlling shareholders often abuse its dominant position to harm other stakeholders' interests of the corporation. Imposing the fiduciary duties to the controlling shareholders is an important legal measure to protect the targeted corporation and the minority shareholders' legitimate rights and interests. This paper describes the theoretical basis, the specific content and protection mechanisms of controlling shareholders' fiduciary duties, so as to provide instructions in improving our legislation.
\end{abstract}

Keywords: Controlling shareholders, Fiduciary duties, Duties of care, Duties of loyalty

\section{Introduction}

The definition of the controlling shareholders is still inconclusive both in theory and practice. The early corporate law theory was based on the capital majority rule to define the controlling shareholders, however, under the modern corporate system which was characterized by dispersed ownership, the standard for people to judge whether a shareholder or certain shareholders has control over the company and identifying the standard of the controlling shareholder are not absolute standard, which is completely in accordance with the certain ratio held by shareholders. In fact, the standard was based on that whether a single shareholder or joint shareholder of the corporation has sustained substantial power and influence. (Note 1).

In response to this feature, in current world, many countries set flexible standard to judge what a controlling shareholder is. The standard includes both essential standard and formal standard. Such as the Principles of Corporate Governance: Analysis and Recommendations, drafted by American Law Institute, defined controlling shareholders from both essential and formal standard. (Note 2). British law was not as the same as the American Law to deal with the definition, the United Kingdom Companies Act provided "shadow director" to define it. In China, the concept of controlling shareholders is mainly used in the academic field, the laws and regulations are still using the" holding shareholder". As for fiduciary duties, it usually refers to the senior management, the directors and managers undertaking the fiduciary duties to the corporation, it does not involve the shareholders. With the rights theory development and abuse, the phenomenon of harming minority shareholders' interests by controlling shareholders continued to occurs, theorists began to extend the fiduciary duties to controlling shareholders. This change in corporate law was a response to the practice, revealed the amendment to the capital majority rule and vote freely principle in traditional corporate law theory, and also reflected the new development of shareholder democracy in traditional corporate law.

\subsection{The Basis of Law and Economics}

The representative of the law economists in the United States supposed that the corporation was a legal fiction, including a series of contractual relations. (Note 3).According to this theory, the relations between the corporation participants were characterized as a contractual relation. Fiduciary duties which imposed on the controlling shareholder by corporate law was considered as a trustee obligation, which make the trustee obligation a kind of "pure contractual obligations.” The corporation was a continuing relational contract, if the corporation contract was 
written in sufficient detail, there was no need for the introduction of fiduciary duties, if it could not be detailed by the company contract provisions to the distinction between the interests, other alternatives could not be found, and the deterrent effect of fiduciary duties replaced its prior supervision. Because setting detailed and clear contract face with high costs in economics, the incomplete contract itself is a contract with loopholes left, the law just provided to eliminate loopholes of the contract, therefore, fiduciary duties set by law not only complemented the loopholes of the contract, but also reduced the transaction costs.

\subsection{The Basis of Jurisprudence}

Justice is the eternal goal of law. Social justice could be divided into formal justice and substantive justice. Formal justice does not take into account the differences of status and strength between the subjects. "The same situation and the same treatment do not guarantee to achieve substantial justice". (Note 4). According to the traditional corporate law, in addition to provide capitals, the controlling shareholders, like other shareholders, have no longer any obligation whether to the corporation or to each other. The provision does not consider the difference of position and strength between controlling shareholders and minority shareholders. It just reflects the formal justice rather than substantial justice. The reality is that based on the control over the corporation, they tend to convert their own will into the corporation's will to infringe upon the interests of the corporation and other shareholders. Based on the fact that controlling shareholders and minority shareholders' strength varies, imposing the fiduciary duties to controlling shareholders can achieve the ultimate goal of justice that the law always purse.

\subsection{The Basis of Corporate Law}

Shareholders equality principle is that according to the shareholder qualification, the legal relations occur between the corporation and shareholders, and also among the shareholders, and all shareholders should get equal treatment by holding shares according to the nature, content and number, so as not to suffer unreasonable treatment. As for the corporation which is controlled by the controlling shareholders, substantive equality means that although the proportion of contributions and shares owned by minority shareholders are small, they are still entitled to the estate benefit right, of which are not allowed to be deprived. As a result of one share one vote and the capital majority rule, minority shareholders' voting rights are engulfed by the controlling shareholder's voting rights. The effect of controlling shareholders' declaration of will expand into the corporation's declaration of will. If the controlling shareholders exercise voting rights reasonably, in accordance with legal procedures, based on legitimate purpose, it will reflect the will of the corporation. If the controlling shareholder abuse the control power, impose their will on the minority shareholders, force them to accept, this will lead to the violation of substantive equality. The general meeting of shareholders reflects the economic democracy in corporation, the implementation of the majority rule is in accordance with the capital rather than the head. We should make sure to avoid the tyranny of the majority, and not only to seek formal equality but also to ensure substantive equality. Thus, the principle of shareholders equality is also a reasonable basis for imposing the fiduciary duties on controlling shareholder.

\section{The Content of Fiduciary Duty of The Controlling Shareholders}

Controlling shareholders' fiduciary duties consists of two aspects: the duties of care and the duties of loyalty, which has been a consensus in the academic community. The duty of care is positive, while the duty of loyalty belongs to the negative.

\subsection{The Duty of Care of The Controlling Shareholders}

The duty of care of the controlling shareholders is that they should possess the duties of care of kindhearted administrator when they deal with general affairs of the corporation. (Note 5).In principle, the following aspects are of use to measure whether the controlling shareholders violate the duties of care.

First, when exercising rights, the controlling shareholders should behave in good faith. It requires them to exercise their rights for the interests of the corporation and all shareholders, not just their own. When these interests are in conflict, they should balance the interests of every related part, and avoid seeking their own interests at the price of other relatives' in the acquisition.

Second, controlling shareholders should perform the duties of care of kindhearted administrator. Decisions and actions relevant to the acquisition should be made to act as a prudent person in the level of attention under similar circumstances. When they take a business action from the corporation's overall interests, under the conditions at that time according to their own level of knowledge and experience, the action should be considered to be the most advantageous one, even if the action causes damage to the corporation , afterwards, the controlling shareholders should not be investigated for responsibility.

Third, the controlling shareholder should exercise rights in a good manner. The controlling shareholder undertake the duty of care under the following situations: selling control, giving instructions to their respective affiliates, and 
supervising the directors and other managers .The controlling shareholders of the targeted corporation in the acquisition make use of its control status and actual advantages of control over the management, this makes to decide which relevant decision to make, what manners and attitudes to deal with the acquisition, such as if anti-takeover should be adopted. In essence, fiduciary duty requires that the actions of controlling shareholders must make in a reasonable manner, which is the way most favorable to the corporation. If adopting anti-takeover can maximize the interests of the corporation and minority shareholders, the controlling shareholders can not hamper to adopting anti-takeover measures for their own sake, otherwise, it can be identified as a violation of duty of care.

Specifically, the controlling shareholders' duties of care are mainly shown as proper investigation duties and information disclosure duties.

\subsubsection{Duties of Proper Investigation}

Proper investigation duties refers to that in the acquisition, the controlling shareholders already predict the acquirer has the possibility to fraud, they undertake the duties to investigate actively on the acquirer's motives and reputation .The core of the duty is that suspicious signs should be investigated when they are found by the controlling shareholders of the targeted corporation. The key element of proper investigation duties is how to identify the "suspicious indications". Some scholars figure out "suspicious indications" which include the followings:

(1)The unusual interest in the current assets or asserts which were realizable assets of the corporation were increased.

(2) Controlling shareholders were asked to transfer the control rapidly.

(3)Adhere to use the endorsement in blank negotiable securities, so that buyers quickly grasp the corporation's current asserts.

However, in commercial practice, the targeted corporation shareholders and corporate control are dynamic, the definition of "suspicious indications" should be varied as the practice change.

\subsubsection{Duties of Information Disclosure}

Duties of Information Disclosure means that during the control transfer, the controlling shareholders should disclose information stage by stage to protect the interests of corporation and minority shareholders, to facilitate effective decision-making and supervision of the securities regulatory authorities. As to the targeted corporation's controlling shareholders, they should seriously consider the timing and content of disclosure. Practice shows that in the acquisition of listed companies, disclose too early may fail in some of the negotiations, while late disclosure is not conducive to the interests of effective regulation and protection of minority shareholders, therefore, disclosure should be by stages. Meanwhile, the control status of controlling shareholders can easily lead to securities fraud, major issues which affect the stock market should be disclosed as soon as possible.

\subsection{The Duties of Loyalty of Controlling Shareholders}

Duties of Loyalty mean that controlling shareholders are forbidden engaging in actions which harm the corporation and other shareholders' interests. According to this duty, when dealing with relevant matter, a fiduciary shall not sacrifice the interests of the trustee or beneficiary to seek his own personal interests, it is a strong moral obligation.

In the acquisition of listed companies, the loyalty duties of the controlling shareholders should include two aspects: First, fraud is forbidden. In the acquisition, controlling shareholders of the targeted corporation's fraudulent action is manifested as information disclosure, misappropriation of corporation property, depression of shares price and so on. These actions will seriously affect the corporation's other stakeholders in the decision-making and behavior choices, directly or indirectly to prejudice their interests.Therefore, the controlling shareholders of the targeted corporation are forbidden fraud in acquisition. Second, related party transactions are limited. Related party transactions are transactions in which targeted corporation's controlling shareholders are most likely to harm the interests of the other stakeholders during the acquisition. In commercial practice, because of the asymmetric information, the minority shareholders and other stakeholders can not fully grasp the background of the controlling shareholders and the purchaser, even the relations between them. In order to relieve the acquisition purpose, the controlling shareholders of the targeted corporation and purchaser often used to take measures to evade the law, which may harm the interests of others, such as restrictions on the entry of other buyers, and refusing to adopt anti-takeover measures. Therefore, restrictions in the acquisition process associated to the targeted corporation's controlling shareholder transactions are in need in the following areas especially:

\subsubsection{Against Securities Fraud}

This obligation includes three elements: First, prohibiting false statements. False statement is the behavior that 
controlling shareholders of the targeted corporation do not disclose the information as required. Second, we should prohibiting market manipulation. Market manipulation is an act that for the purpose of obtaining the benefits or minimizing loss, controlling shareholders use its information or dominant position to manipulate stock prices. Third, we should prohibiting insider trading. Insider trading refers to the insiders use insider information engaging in securities trade activities, disrupt the stock market order, impair the interests of the corporation and minority shareholders. Acquisition information is information that can lead to significant price volatility, and controlling shareholders of the targeted corporation who are regard as the insiders can easily use its position in the insider trading.

\subsubsection{Against Impure Motive of Corporate Behaviors}

In the acquisition process, if the controlling shareholders do not want to transfer the control, they often use their controlling position to manipulate the management to initiate anti-tender offer campaign in the name of the corporation's development. This is the impure motive of corporate behaviors by targeted corporation's controlling shareholders. This act in fact violates the minority shareholders and the corporation's interests, so it should be prohibited. (Note 6).

\subsubsection{Against Usurping Corporation's Opportunity}

If the controlling shareholders of targeted corporation usurp other shareholders' opportunity to sell their shares or properties at higher price during the control transfer, therefore, the controlling shareholders violate the duties of loyalty, the control transfer premium should be resumed by the corporation or other shareholders. Obvious example shows that when the acquirer proposes an attractive price to buy the property or shares of the corporation ,but the controlling shareholder has proposed to buy its controlling stake only, in such cases, the opportunity to sell property with remunerative price belong to all shareholders ,it should not be exclusively owned by the controlling shareholder. (Note 7).

\subsubsection{Against Transferring Manager Positions}

After the control transfers, the new controlling shareholders does not certainly control the board of director, in order to ensure the new controlling shareholders' control over the company early, sometimes transaction parties through the high premium of control to make agreements with controlling shareholders one provision, which commonly referred as "sequential resignation and the appointment of terms". In such cases, new controlling shareholders replace the recommended candidates. However, many judges and scholars believe that transferring manager positions contravene the public policy and its premium is the manager positions pay price. (Note 8).Therefore, the premium should be resumed by the corporation. The key issue actually is not in the ownership of a premium ,but in the control transfer when targeted shareholders abuse their control so as to improve the conditions of their own, thus seriously harm the interests of corporation and minority shareholders, it is a violation of the duties of loyalty.

\section{The Guarantee Mechanism for the Fiduciary Duties of Controlling Shareholders}

One of the important roles of the law is to adjust and reconcile the various conflicting interests. When the interest conflicts occur between controlling shareholder and minority shareholders, an appropriate law system should be established to balance the relations between them. Therefore, the system should be designed to be rigorous and scientific in order to regulate behavior of controlling shareholders and provide a strong legislative measure to protect the system. Establishing and advancing the supervision of the controlling shareholder fiduciary duty and the obligations mechanisms of accountability are of great importance.

\subsection{Procedural Guarantee Mechanism-Classified Voting System}

The so-called classified voting system is defined as follows: in listed corporation, when voting on matters that could harm stock shareholders interest, if the motion of a general shareholder meeting affects different types of shareholders differently, there is a need to give the different classes of shareholders with special voting rights. Many countries have laws and charts of the classified voting system. Among which the U.S. common law, "Standard Act" has the most detailed provisions. To sum up, this requirement mainly exists in the charts changes and conflict of interest transactions. Because different types of the shareholders have different rights, in order to ensure substantive equality, it is necessary to introduce classified voting system to comply with procedural justice. Such as the motion involved with classified shareholders needs its class shareholders and other class shareholders consider it respectively, and the motion is adopted by majority. It is a fair rule, in essence, a way of shareholder autonomy, through advance monitoring to prevent the abuse control power.

\subsection{Supervision Guarantee Mechanism}

The misuse of capital majority leads to the harm to the interests of the corporation, the other minority shareholders 
and the creditors of the company. Therefore, there is a high need to improve the supervision guarantee mechanism, including independent directors system and board of supervisors system.

\subsubsection{Independent Directors System}

Independent directors, also known as "external directors", it do not actually execute the business, and also have no interested relation with the corporation and control. Toward the process to Director-centrism in the corporate governance structure, the introduction of independent directors can ensure board's basic control over the company. In other countries, dispersed ownership and the separation between senior management and shareholders are viewed as a precondition, independent directors is representative of all shareholders in a sense, it is a means to solve the lack of shareholders' control power, it can restrict the use of their control status to make actions which harm outside shareholders of the corporation so as to reduce the problems caused by the internal controller.

\subsubsection{Board of Supervisory System}

Board of Supervisors System is a monitoring mechanism of power balances, which can effectively reduce the agency costs and moral hazard of the controlling shareholders. In order to constrain the corporation's controller, in essence, it need getting rid of controlling shareholders' unconstrained control over the corporate property so as to balance the power of related subjects of the company, and even the ultimate balance of interests. The law stipulates that the controlling shareholders assume the fiduciary duties to corporation, however, the board of supervisors system is the company's internal supervision mechanisms, and also the best preventive measures to protect the controlling shareholders' fiduciary duties system.

\subsubsection{Accountability Mechanisms}

(1) The System of Shareholder's Representative Suit

The system of shareholder's representative suit, also called derivative suit, was established by Equity. When the company suffers from illegal violation, the company is negligent of the litigation, for the sake of the company, the shareholder or other related ones who meet the legal requirement can appeal in their names, pursue its legal responsibility. When the controlling shareholders harm the company and other minority shareholders' interests, the company is negligent of the litigation due to the internal control, the damages which the minority shareholders suffer will not receive remedy. The most desirable way is to determine the form of legal action on behalf of shareholders to give them the right to initiate a representative suit.

(2) Rescinded Action or Invalid Action to General Shareholder Meeting

Resolution which is adopted by controlling shareholders through a majority vote of the legal process may also damage the interests of the subsidiary company and minority shareholders. Therefore, the most of countries' law grant minority shareholders the right to initiate a rescinded action or a invalid action to remedy, such as France, Austria, Japan, South Korea..

\section{References}

Press Release, Claudia H. Allen, Neal, Gerber, \& Eisenberg LLP. (2007). Majority Voting in Director Elections—An Activist Success Story (Nov. 13).

Lucian Arye Bebchuk. (2005). The Case for Increasing Shareholder Power, 118 HARV. L. REV. 833.

LewisD. (1988). Solomonetal.Corporations Law and Policy Materials and Problems, (2nd ed,).Minnesota:West Publishing C0.

Paul L. Davies. (1997). Grwer's Principles of Modern Company Law, Sweet \& Maxwell, Six Edition.

Anabtawi, Iman \& Stout. (2008). Fiduciary Duties for Activist Shareholders, Stan.l.Rev.Vol.60.

Easterbrook, Frank H \& R.Gischel. (1982).The Economic Structure of Corporate Law, Hague:Harvad University Press.

Jesse Fried \& David Walker. (2002). Managerial Power and Rent Extraction in the Design of Executive Compensation, 69 U. Chi. L. Rev. 751, 764-83..

Frank H. Easterbrook \& Daniel R. Fischel. (1989). The Corporate Contract, 89 Colum. L. Rev. 1416.

Notes

Note 1.Shenshi mei: The Power Structure of Modern Corporate Authority: Legal Analysis of Corporate Governance. China Politics and Law University Press, 1996, p. 212.

Note 2.Wang,Baoshu,Yang,Ji:TheObligations and Responsibilities of The Stock Company's Controlling 
Shareholders .Law 2002.

Note 3.RW Han-dense and Washington: Company Law. China Renmin University Press, 2001, p. 6.

Note 4.Shen Zongling:ModernWestern Science. Peking University Press, 1992:120.

Note 5.Zhang Fang: the acquisition of the legal system. Law Press, 1998 Edition, pages 211-213.

Note6.Lews D. Solomon, Danald E. Schuwartz \& Jeffery D Banman, Corporations and Policy, Materials and Problems, and ed.p1000 (1998).

Note 7.American Standard Companies Act section 32,article 59,article 60.

Note8.Wang Yucheng: "Company Law of the controlling shareholders of fiduciary duty breach of the Prevention and Relief,” contains “Guangdong Administration Institute” August 20084 